\title{
Poprawa jakości lutowania elementów z układów chłodniczych i klimatyzacyjnych w piecach $z$ atmosferą kontrolowaną
}

\section{Increase of brazing quality in controlled atmosphere furnaces of refrigeration and air conditioning system components}

\section{Streszczenie}

W artykule przedstawiono sposoby poprawy jakości produkowanych elementów układów chłodniczych i klimatyzacyjnych przez zmianę warunków lutowania w piecach z atmosferą kontrolowaną. Stosując odpowiedni dobór parametrów technologicznych, uzyskano połączenia lutowane o bardzo dobrej jakości. Dzięki badaniom metalograficznym ujawniono przyczyny źródłowe problemów i sposoby ich eliminacji.
Abstract

The paper presents ways to improve the quality of manufactured refrigeration and air conditioning system components by changing the brazing condition in furnaces with controlled atmosphere. Through the selection of technological parameters obtained solder joints with very good quality. With metallurgical tests revealed the root causes of problems and their solutions.

\section{Wstęp}

W zakładzie wytwarzającym elementy wchodzące w skład układów chłodniczych i klimatyzacyjnych produkcja opiera się na trzech strumieniach wartości, do których należą [1]:

- Strumień wartości osuszaczy powietrza:

Są to produkty pełniące funkcję filtrów i osuszaczy powietrza. Wewnątrz zbiornika zależnie od modelu osuszacza znajduje się: sito molekularne w postaci granulatu wiążące wilgoć z układu, aktywny tlenek aluminium, którego zadaniem jest związanie kwasu wytrącającego się z czynnika chłodzącego w systemie klimatyzacyjnym oraz filtry mechaniczne, takie jak włóknina.

Prof. dr hab. inż. Zbigniew Mirski, mgr inż. Adam Kuta Politechnika Wrocławska.
- Strumień wartości wskaźników wilgotności:

Są to produkty pełniące funkcję wskaźnika wilgotności. Jeżeli czynnik przepływający przez dany wskaźnik zawiera wilgoć, to znaczy że osuszacz powietrza zmontowany przed wskaźnikiem nie spełnia swojego zadania i należy go wymienić.

- Strumień wartości filtrów olejowych:

Są to produkty pełniące funkcję filtrującą lub wygłuszającą. Czynnikiem jest olej mineralny.

Analiza statystyczna występujących niezgodności w produktach pozwoliła na określenie głównej przyczyny problemu. Okazało się, że 70\% kosztów złomowania wyrobów powodują wady związane z procesem lutowania piecowego. W celu poprawy wewnętrznego wskaźnika COPQ (Cost of Poor Quality) skupiono się na analizie niezgodności występujących w procesie lutowania piecowego. 


\section{Materiały stosowane w procesie lutowania}

Do materiałów podstawowych zaliczono materiał elementów łączonych. Wyróżnia się następujące elementy materiałów spajanych:

a) rurki miedziane $\mathrm{w}$ stanie twardym o czystości $99,998 \%$ wag. $\mathrm{Cu}$,

b) konektory ze stali automatowej 11SMMPB37 powlekane galwanicznie warstwą niklu o grubości $8 \div 13 \mu \mathrm{m}$,

c) konektory ze stali automatowej 11SMMPB30 powlekane galwanicznie warstwą miedzi o grubości $25 \div 33 \mu \mathrm{m}$,

d) konektory, korpusy ze stali automatowej $95 \mathrm{MnPb} 36$,

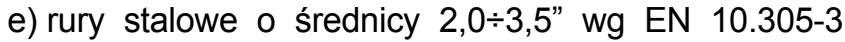
E-220,

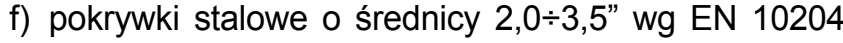
DC04,

g) pokrywki stalowe o średnicy $121 \mathrm{~mm}$ wg EN 10111 DD13.

Materiały dodatkowe do lutowania stanowią luty oraz gazy tworzące atmosferę kontrolowaną:

- lut miedziany Cu 922 wg PN-EN ISO 17672 [2], stosowany w postaci pierścionków o średnicy drutu $0,7 \div 3 \mathrm{~mm}$ i średnicy wewnętrznej $17 \div 76 \mathrm{~mm}$. W tablicy I zamieszczono skład chemiczny, oraz temperaturę topnienia lutu $\mathrm{Cu} 922$

- lut miedziany Cu 141 wg PN-EN ISO 17672 [2], stosowany w postaci pierścionków o średnicy drutu $2.75 \div 3,00 \mathrm{~mm}$ i średnicy wewnętrznej $22 \div 28 \mathrm{~mm}$. W tablicy II zamieszczono skład chemiczny oraz temperaturę topnienia lutu Cu 141

- atmosfera kontrolowana: stanowią ją wodór lub mieszanina wodoru $z$ azotem oraz mieszanina gazu ziemnego wysokometanowego typu E z powietrzem.

Stosuje się następujące kombinacje zespołów lutowanych:

- lut Cu 922: a-f; a-d, b-f, c-f, d-f, d-g, e-f,

- lut Cu 141: b-f, d-f, d-g

Tablica I. Skład chemiczny i temperatura topnienia lutu Cu 922 [2] Table I. Chemical composition of the copper alloy Cu 922 [2]

\begin{tabular}{|c|c|c|c|c|}
\hline \multirow{2}{*}{ Oznaczenie } & \multicolumn{3}{|c|}{$\begin{array}{c}\text { Zawartość składników, } \\
\% \text { wag. }\end{array}$} & \multirow{2}{*}{$\begin{array}{c}\text { Temperatura } \\
\text { topnienia, }\end{array}$} \\
\cline { 2 - 4 } & $\mathrm{Cu}$ & $\mathrm{Sn}$ & $\mathrm{P}$ & \\
\hline Cu 922 & reszta & $5,5 \div 7,0$ & $0,01 \div 0,40$ & $910 \div 1040$ \\
\hline
\end{tabular}

Tablica II. Skład chemiczny i temperatura topnienia lutu Cu 141 [3] Table II. Chemical composition of the copper alloy Cu 141 [3]

\begin{tabular}{|c|c|c|c|c|}
\hline \multirow{2}{*}{ Oznaczenie } & \multicolumn{3}{|c|}{ Zawartość składników, } & \multirow{2}{*}{ Temperatura } \\
\cline { 2 - 4 } & $\mathrm{Cu}$ & $\mathrm{Al}$. & $\mathrm{P}$ & topnienia, ${ }^{\circ} \mathrm{C}$ \\
\hline $\mathrm{Cu} 141$ & 99,90 & 0,01 & $\begin{array}{c}\max \\
0,075\end{array}$ & 1085 \\
\hline
\end{tabular}

\section{Konstrukcja elementów lutowanych}

Około $80 \%$ połączeń lutowanych składa się z konektora stalowego (miedziowanego lub niklowanego) umiejscowionego w otworze pokrywki. Konektory niklowane są gwintowane, a konektory miedziowane wykonywane są z końcówką gładką. Na obwodzie konektora pozycjonowany jest pierścionek lutu. Średnica drutu lutu jest zależna od obwodu konektora. Na rysunku 1 pokazano konstrukcję połączenia lutowanego.

Kolejne połączenie dotyczy konektora miedzianego i pokrywki z kołnierzem (rys. 2). W pokrywce wykonany jest kołnierz, którego zadaniem jest pozycjonowanie konektora miedzianego i utworzenie styku na obwodzie.

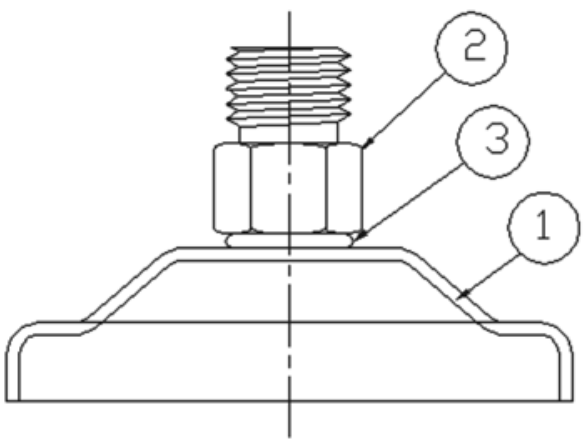

Rys. 1. Zespół lutowany z konektorem stalowym: 1 - pokrywka, 2 - konektor stalowy, 3 - pierścionek lutu

Fig. 1. Brazed subassembly with steel connector: 1 - end cap, 2 - steel connector, 3 - braze ring

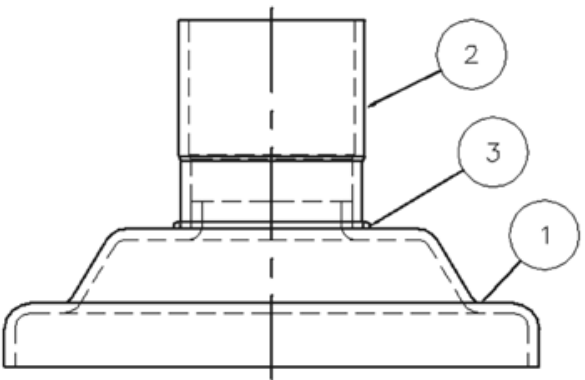

Rys. 2. Zespół lutowany $z$ konektorem miedzianym: 1 - pokrywka $z$ kołnierzem, 2 - konektor miedziany, 3 - pierścionek lutu

Fig. 2. Brazed subassembly with copper connector: 1 - collar end cap, 2 - copper connector, 3 - braze ring

\section{Technologia lutowania w piecach z atmosferą kontrolowaną}

Lutowanie przeprowadza się $\mathrm{w}$ przelotowych piecach typu BTU Transheat $\circledast$ Controlled Atmosphere i SCAME (rys. 3a, b). Są one dostosowane do lutowania podzespołów filtrów osuszających i olejowych [3, 4]. Są to piece tunelowe, w których transport detali odbywa się za pomocą pasa transmisyjnego. W celu uzyskania wymaganej temperatury lutowania stosowane jest nagrzewanie oporowe. Atmosfera pieca typu BTU 
może być wytworzona przez wprowadzenie wodoru lub mieszaniny wodoru $z$ azotem. Atmosfera pieca SCAME jest wytwarzana za pomocą reakcji odwodornienia mieszaniny gazu ziemnego. Do głównych parametrów wpływających na proces lutowania piecowego należą: prędkość taśmy, temperatura stref pieca, skład atmosfery, przepływ gazu, poziom spalin. Na wejściu do pieca znajdują się kurtyny, których zadaniem jest utworzenie fizycznej bariery pomiędzy zewnętrznym środowiskiem a komorą procesową. Na wejściu i wyjściu pieca zlokalizowane są dysze, które doprowadzają azot w celu izolacji gazu procesowego, jakim jest mieszanina wodoru i azotu.
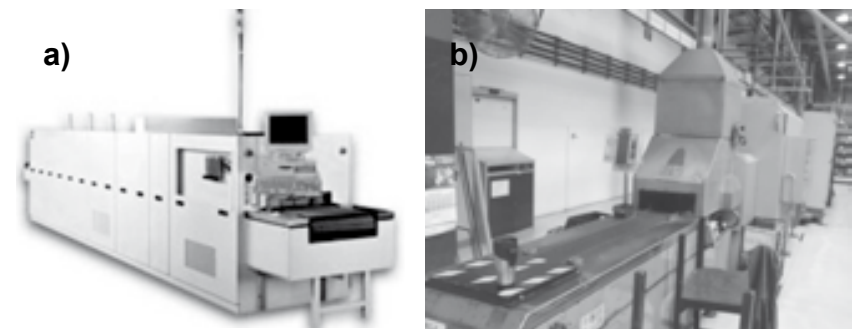

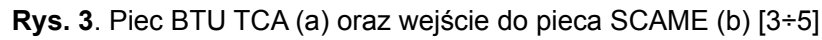
Fig. 3. BTU TCA oven (a) and SCAME oven Entrance (b) $[3 \div 5]$

\section{Wady połączeń lutowanych i sposoby ich unikania}

Wszystkie produkowane wyroby spełniają wymogi dyrektywy UL/PED. Norma określa ciśnienie wybuchowe dla zbiorników. Jest to zwykle ciśnienie będące 5-krotną wartością maksymalnego ciśnienia pracy. Produkt musi wytrzymać określone naprężenie powyżej jednej minuty. Wszystkie wyroby poddawane są 100\% kontroli szczelności przy użyciu testerów helowych. Zbiornik podczas testu zamykany jest w komorze próżniowej napełnianej helem. Spektrometr sprawdza jakość połączeń lutowanych i spawanych. Poziom odrzutu detali wynosi 1,2.10 $\mathrm{EE}^{-5} \mathrm{~atm} \mathrm{cc} / \mathrm{s}$. Do testów wytrzymałościowych stosowana jest maszyna wytrzymałościowa włoskiej firmy BIMAL. Produkt nie może ulec zniszczeniu w obszarze połączeń lutowanych, spawanych lub na szwie rury. Aby zapewnić dobrą jakość produkcji wyrobów wymagane są akcje korygujące dla wszystkich problemów, które powodują obniżenie wyników głównych wskaźników: bezpieczeństwa, jakości, dostawy, czasu, produktywności, kosztów magazynowania. Wskaźnik jakości związany jest z ilością reklamacji otrzymanych od klienta (RPPM), jak również wskaźnikiem COPQ. W celu poprawienia wyników przeprowadzono wiele zabiegów korygujących, związanych z dobraniem odpowiednich parametrów pieca. Na rysunku 4 przedstawiono wykres jakości połączeń lutowanych opracowany na podstawie trzech lat produkcji.

Głównym problemem jakościowym był znaczny odrzut produktów na testerze helowym (przecieki). Po weryfikacji produktów na testerze wodnym, okazało się, że $80 \%$ przecieków było spowodowanych pęknięciami w połączeniu spawanym (rys. 5).

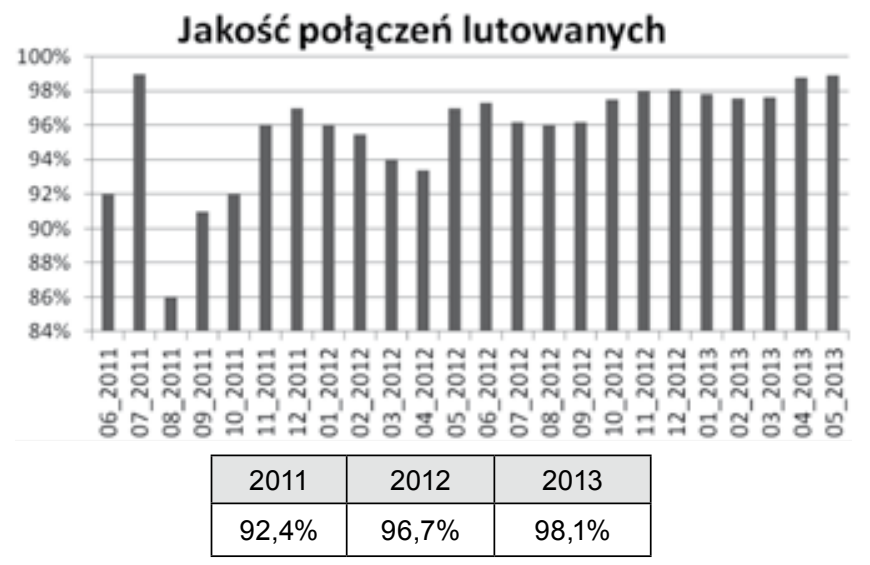

Rys. 4. Wykres jakości połączeń lutowanych

Fig. 4. Braze joint quality graph

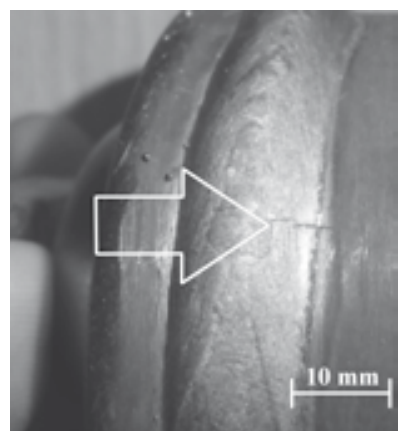

Rys. 5. Widoczne pęknięcie w spoinie

Fig. 5. Crack on the welding joint

Pęknięcia pojawiały się tylko w zbiornikach, których podzespoły były wcześniej lutowane spoiwem miedzianym w piecu. Wykonano badania metalograficzne, które wykazały obcy materiał w strefie pęknięcia. Po pomiarze gęstości obcego materiału okazało się, iż jest to stop lutu miedzianego stosowanego w procesie lutowania (rys. 6).
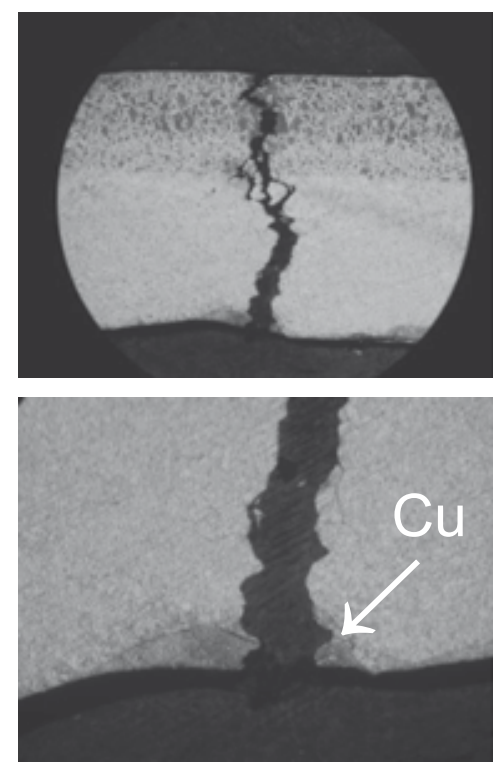

Rys. 6. Pęknięcie stalowej rury spowodowane obecnością miedzi, trawiono chemicznie $2 \%$ Nitalem

Fig. 6. Crack on the tube due to copper, chemical etching $2 \%$ Nital 
Badania wizualne zespołów lutowanych wykazały, że $70 \%$ pokrywek było zalanych lutem w miejscu spawania. Temperatura w piecu tunelowym jest zależna od wypełnienia przestrzeni roboczej pieca. Zwiększenie załadunku pieca obniża profil temperaturowy pieca, a tym samym prawdopodobieństwo nadmiernego rozlania lutu w strefie połączenia spawanego. W celu wyeliminowania zjawiska nadmiernego rozpłynięcia lutu zwiększono dwukrotnie załadunek pieca dla pokrywek dzięki użyciu metalowych płaskowników jako podkładki (rys. 7). Dla zespołów o najmniejszej średnicy zastosowanie płaskowników było niewystarczające (taki sam poziom rozpływania się lutu przy średnicy pokrywki równej 2" powodował w dalszym ciągu pęknięcia podczas spawania). Aby otrzymać połączenie bez pęknięć, zwiększono prędkość taśmy z 4,8 do 5,20 cal/min. Dzięki tym zabiegom nie pojawiły się już pęknięcia w spoinie, tym samym poprawiono jakość produktu o $2 \%$.

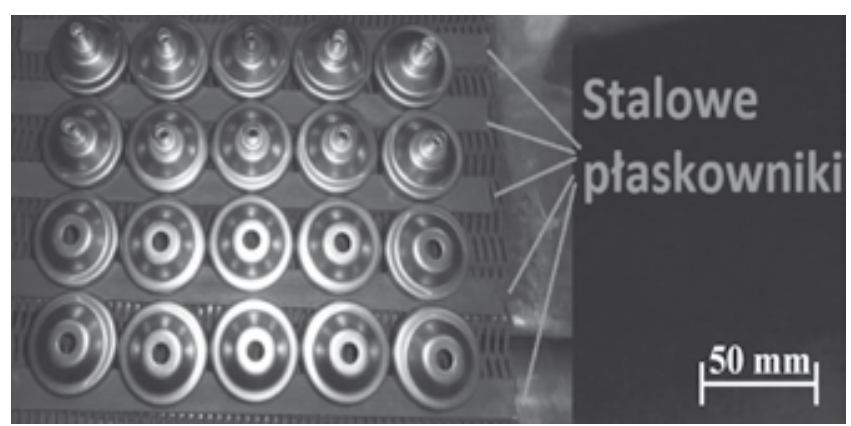

Rys. 7. Zwiększenie załadunku pieca BTU przy użyciu stalowych płaskowników

Fig. 7. Increase of belt load due to steel bars

W kolejnym przypadku, podczas wprowadzania nowego produktu, pojawił się problem z nadmiernym rozpłynięciem lutu w miejscu spoiny, oraz z dużą ilością nieszczelnych połączeń lutowanych. Ilość dobrze polutowanych produktów wynosiła ok. 80\%. Konstrukcja złącza była nieoptymalna dla połączenia lutowanego (nierównomierna i zbyt szeroka szczelina lutownicza). Brak możliwości zmiany konstrukcji połączenia spowodował szukanie rozwiązań zastępczych. Wszelkie próby zmiany parametrów lutowania jedynie pogarszały jakość produktu. Zwiększenie obciążenia pasa pieca powodowało brak odpowiedniego rozpływania się lutu (poprzedni przypadek zastał rozwiązany tylko zmianą obciążenia pieca). W celu uniknięcia nadmiernego rozpłynięcia lutu w miejscu połączenia spawanego zastosowano jako barierę marker olejowy (rys. 8). Dzięki temu zabiegowi lut pozostawał w obszarze złącza (brak problemów z pękaniem spoiny) [5].

Następne problemy z nieszczelnymi połączeniami lutowanymi były spowodowane stosowaniem specjalnych nakładek do pozycjonowania konektorów. Użycie ich wynikało z nieoptymalnej konstrukcji złącza (brak powierzchni wspierającej konektor). Stosowanie suportów pomagało w utrzymaniu prostych konektorów podczas procesu lutowania, lecz również ze względu na ich masę odbierało znaczną ilość ciepła (rys. 9).
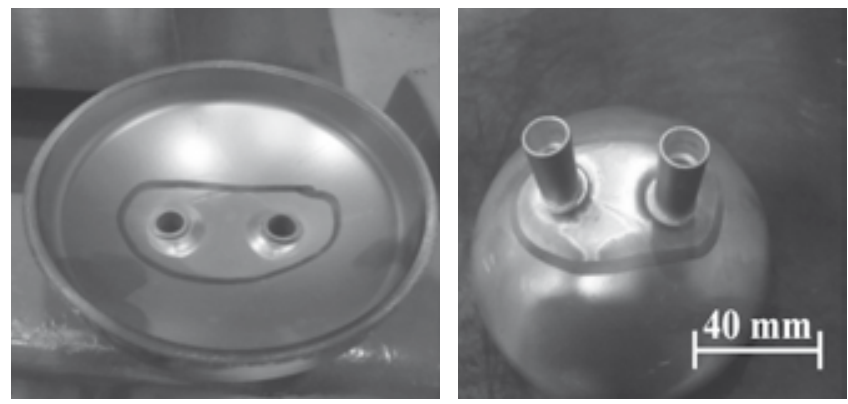

Rys. 8. Uniknięcie nadmiernego rozpłynięcia lutu za pomocą markera olejowego

Fig. 8. Lack of alloy overflowing due to marker block

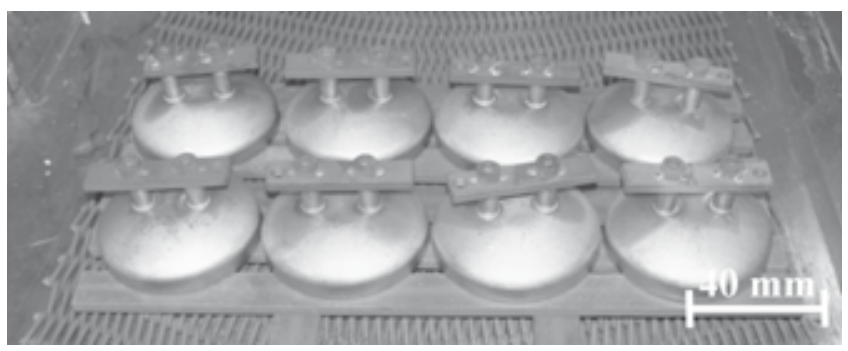

Rys. 9. Załadunek pieca BTU pokrywkami wraz z wspornikami Fig. 9. Load of the BTU oven with end cap and supports

Proces lutowania tych pokrywek był bardzo trudny. Jakakolwiek zmiana parametrów lutowania (załadunek pieca oraz prędkość przesuwu taśmy) nie przynosiła pozytywnych wyników.

Wszystkie wyroby kontrolowano na dodatkowym testerze, złe podzespoły złomowano. Dopiero zastosowanie odmiennego punktu widzenia pomogło uzyskać $98 \%$ jakości za pierwszym razem dla lutowanych zespołów. Zmieniono sposób załadunku detali, który pokazano na rysunku 10. Tym sposobem otrzymano grawitacyjną blokadę rozpływania się lutu po powierzchni pokrywki (brak potrzeby stosowania markera). Lut znajduje się w odpowiednim miejscu, dzięki czemu poprawia się szczelność wyrobu.

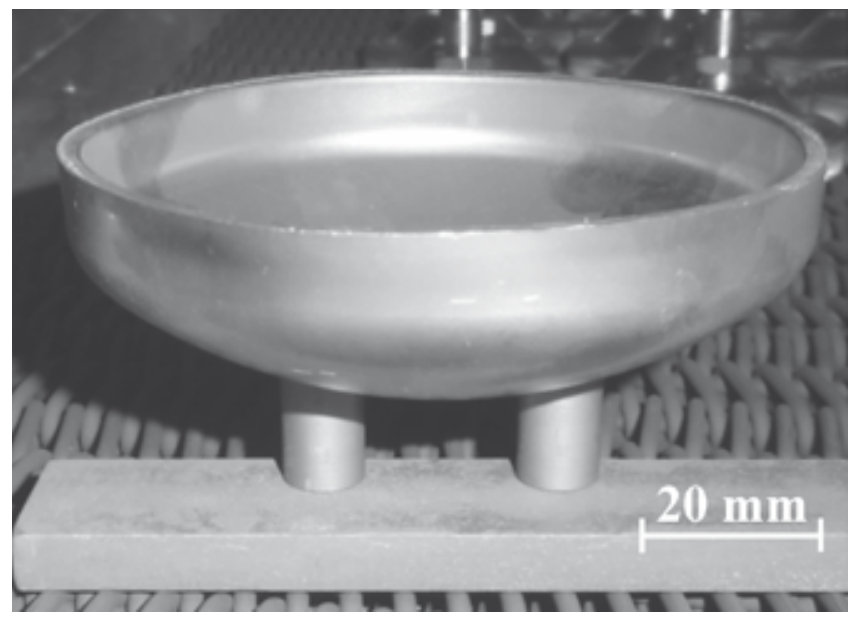

Rys. 10. Nowy sposób załadunku pieca BTU pokrywkami Fig. 10. New load method end cap in BTU oven 
Jeden z większych problemów jakości połączeń lutowanych dotyczył zespołów filtrów olejowych. Detale te są łączone za pomocą pierścionków miedzianych. Standardowy proces produkcji wykonywany jest w piecu SCAME ze względu na możliwość uzyskania odpowiednio wysokiej temperatury lutowania $\left(1145^{\circ} \mathrm{C}\right)$. Podczas remontu pieca SCAME jedynym rozwiązaniem podtrzymania produkcji było użycie pieca BTU. Zastosowanie pierścionków miedzianych było niemożliwe ze względu na ograniczenia temperaturowe. Zmieniono lut $\mathrm{Cu} 141$ (o składzie w \% wag.: 99,98\% Cu, $0,02 \%$ P) na Cu $922(93,43 \% \mathrm{Cu}, 6,35 \% \mathrm{Sn}, 0,22 \% \mathrm{P})$ wg PN-EN ISO 17672. Pierwsze próby lutowania dały efekty jakościowe na poziomie $35 \%$, co wynikało z braku szczelności i niepoprawnej pozycji dystansowania elementów (rys. 11).

Opadanie tulei dystansowej uniemożliwiała zbyt duża ilość nieroztopionego lutu przy powierzchni zespołu lutowanego (rys. 12).

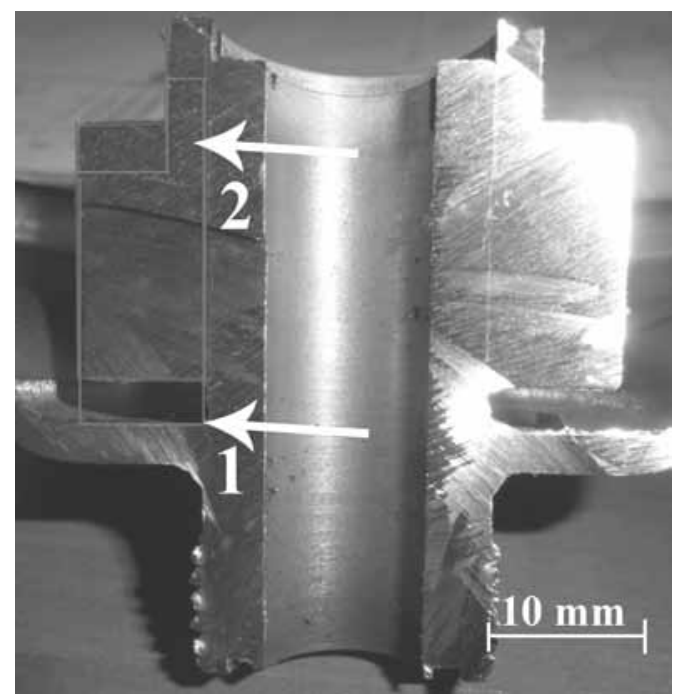

Rys. 11. Przekrój polutowanego zespołu filtra olejowego; 1 - poprawna pozycja tulei dystansowej, 2 - niezgodna pozycja tulei dystansowej

Fig. 11. Cross section of oil filter; 1 - proper position of spacer, 2 - wrong position of spacer

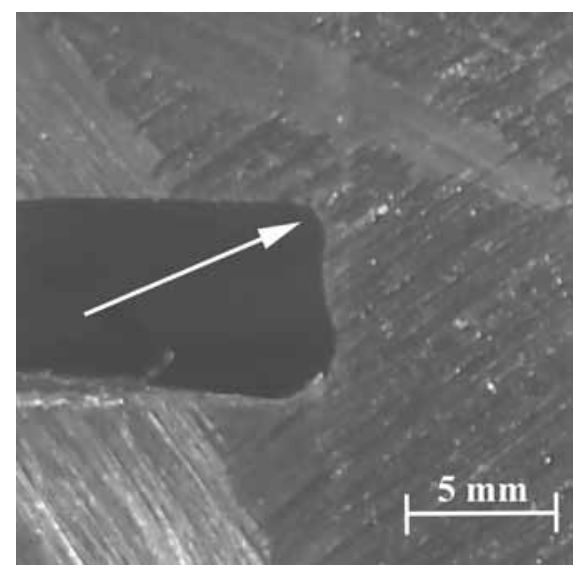

Rys. 12. Klin lutu uniemożliwiający opadanie tulei dystansowej Fig. 12. Alloy skid cause issue with proper spacer position
W celu sprawdzenia rozkładu temperatury wykonano pomiary profilu temperaturowego pieca (tabl. III). Czas powyżej temperatury płynięcia był niedostateczny. Zmniejszono załadunek pieca o $25 \%$. Jakość połączeń pogorszyła się do poziomu $29 \%$. Pomimo zmniejszonego załadunku ponowny profil pieca pokazał skrócony czas w obszarze temperatury płynięcia lutu (tabl. IV).

Przeprowadzono próbę ze zwiększonym załadunkiem pieca o 50\%. Jakość zespołów lutowanych ustabilizowała się na poziomie $99,8 \%$. Profil temperaturowy pieca wykazał ponad dwukrotnie dłuższy czas dla temperatury w obszarze płynięcia lutu Cu 922 (tabl. V).

Tablica III. Czas płynięcia lutu Cu 922 - stan wyjściowy Table III. Time over melting point for Cu 922 alloy - first trial

\begin{tabular}{|c|c|c|}
\hline Produkt & Masa, $\mathrm{kg} / \mathrm{mb}$ & Czas powyżej $1040^{\circ} \mathrm{C}, \mathrm{s}$ \\
\hline Pokrywka & 40 & 167 \\
\hline
\end{tabular}

Tablica IV. Czas płynięcia lutu - redukcja masy załadunku o $25 \%$ Table IV. Time over melting point - decreased load by $25 \%$

\begin{tabular}{|c|c|c|c|}
\hline Produkt & Data & $\begin{array}{c}\text { Masa, } \\
\mathrm{kg} / \mathrm{mb}\end{array}$ & $\begin{array}{c}\text { Czas powyżej } \\
1040^{\circ} \mathrm{C}, \mathrm{s}\end{array}$ \\
\hline Pokrywka & $2013-01-17$ & 30 & 141 \\
\hline
\end{tabular}

Tablica V. Czas płynięcia stopu lutu - zwiększenie załadunku o $50 \%$ Table V. Time over melting point - increased load by $50 \%$

\begin{tabular}{|c|c|c|}
\hline Produkt & Masa, kg/mb & Czas powyżej $1040^{\circ} \mathrm{C}, \mathrm{s}$ \\
\hline Pokrywka & 60 & 297 \\
\hline
\end{tabular}

Logiczne wydaje się że, podczas zmniejszania załadunku pieca powinno się otrzymać większą zdolność do nagrzewania zespołów lutowanych. W powyższym przypadku wyniki badań wskazały na sytuację odwrotną. Powodem tego jest zarówno konstrukcja złącza, jak i jego masa. Detal lutowany po zaabsorbowaniu energii cieplnej utrzymywał ją na poziomie płynięcia lutu przez 297 s. Uwalnianie energii w cieplnej strefie chłodzenia jest wolniejsze dla detali o większej masie. Zrozumienie tego problemu pozwoliło na optymalizację i dobór parametrów lutowania dla wszystkich zespołów lutowanych filtrów olejowych. Uzyskano poziom jakości połączeń lutowanych równy $98,9 \%$ [5].

Lutowanie $w$ piecach przelotowych odbywa się zwykle w systemie dwuzmianowym od poniedziałku do piątku. W celu oszczędności energii temperatura pieca BTU jest zmniejszana do wartości $800^{\circ} \mathrm{C}$ na dni wolne od pracy. Przy ponownym rozpoczęciu produkcji w poniedziałek konieczny jest długi czas stabilizacji pracy pieca (temperatura, atmosfera) wynoszący około pięć godzin. Zmniejsza to produktywność zakładu, ponieważ $90 \%$ procesów produkcyjnych związanych jest z pracą na zespołach lutowanych. 
Zespoły, które lutowano przed ukończeniem procesu wytwarzania atmosfery, cechowały się jakością na poziomie tylko $30 \%$ szczelnych połączeń. $\mathrm{Na}$ detalu widoczne jest niedolanie lutu pomimo zgodnego profilu temperaturowego (rys. 13). Powierzchnia zespołów pokrywała się tlenkami ograniczającymi zwilżalność lutu (rys. 14). W celu przyspieszenia czasu stabilizacji pieca wykonano serie prób. Pierwsza próba polegała na gęstym układaniu balastu w czasie rozruchu i dogrzewaniu pieca. Czas stabilizacji zmniejszył się o dwie godziny.

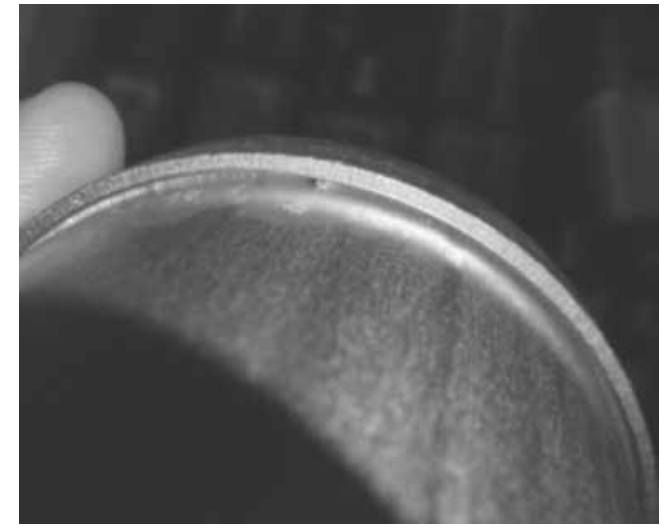

Rys. 13. Niedolanie lutem pokrywki zespołu lutowanego Fig. 13. Lack of brazed subassembly alloy penetration

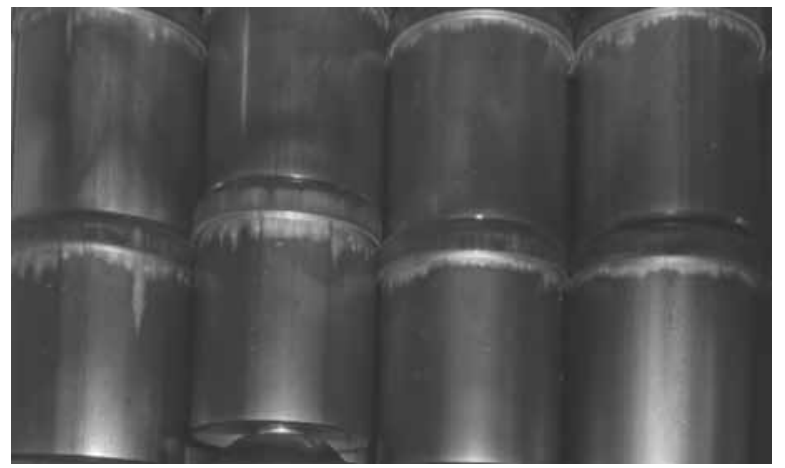

Rys 14. Utleniona powierzchnia zespołów lutowanych

Fig. 14. Oxidised surface of subassemblies

W celu skrócenia czasu stabilizacji pieca zmieniono parametry atmosfery ochronnej. Zwiększono zawartość wodoru w mieszaninie z 8 do $20 \%$ obj. (na czas stabilizacji). Dało to możliwość rozpoczęcia produkcji po jednej godzinie. Tym samym uniknięto problemów jakościowych z nieszczelnymi wyrobami pierwszej serii produkcyjnej.

Głównymi wymaganiami stawianymi produkowanym filtrom są szczelność oraz wytrzymałość mechaniczna. Wymagania te zmniejsza erozja powstająca na powierzchni konektorów miedzianych, spowodowana oddziaływaniem lutu (rys. 15).

W celu uniknięcia erozji zmieniono parametry lutowania. Zmniejszono temperature lutowania $\circ 5^{\circ} \mathrm{C}$ w każdej strefie grzejnej pieca SCAME i było to skutecznym rozwiązaniem problemu. Wprowadzone działania pozwoliły na poprawę wyników jakościowychz 92,4 do $98,1 \%$. Pozostałe problemy związane z połączeniami

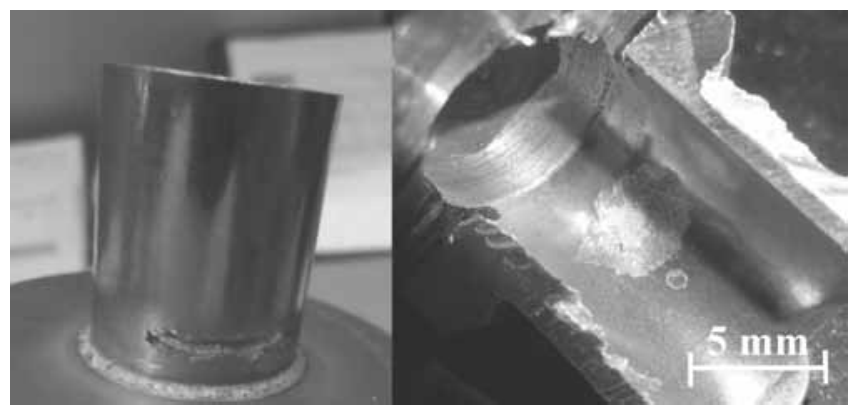

Rys. 15. Erozja na konektorach miedzianych

Fig. 15. Errossion on copper connector

lutowanymi dotyczyły pojedynczych nieszczelności. Ich analiza w celu wyjaśnienia przyczyny przecieku oraz sugerowane propozycje rozwiązania problemu przedstawiono na podstawie badań metalograficznych.

\section{Badania metalograficzne połączeń lutowanych}

Analiza jakościowa wykazała potrzebę wykonania badań na czterech podzespołach lutowanych sprawiających największe problemy ze szczelnością połączeń. Wszystkie detale lutowano zgodnie z parametrami ustalonymi za pomocą powyższych zmian $w$ procesie lutowania. Badania wykonano na nieszczelnych zespołach, ocenionych podczas testu helowego. Do badań metalograficznych pobrano próbki z wykazaną nieszczelnością podczas badań penetracyjnych. Miejscem badań był obszar, w którym znajdowała się nieszczelność, widoczna dzięki czerwonemu kolorowi penetrantu (rys. 16).

Badania metalograficzne ujawniły znaczną porowatość i braki wypełnienia szczeliny lutowniczej (rys. 17).
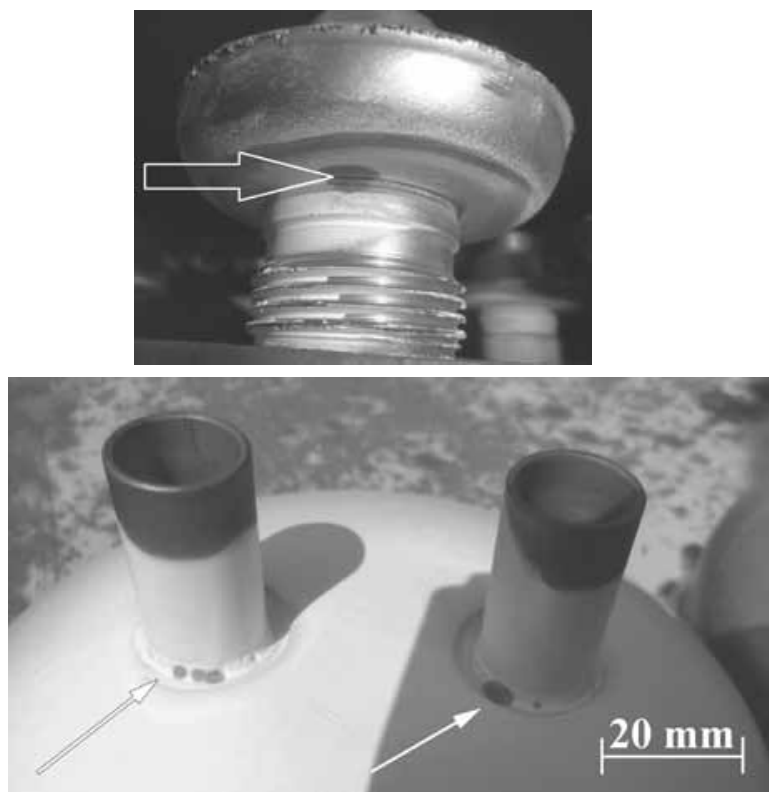

Rys. 16. Miejsce przecieku ujawnione za pomocą testu penetracyjnego Fig. 16. Leak path visible due to penetration test 

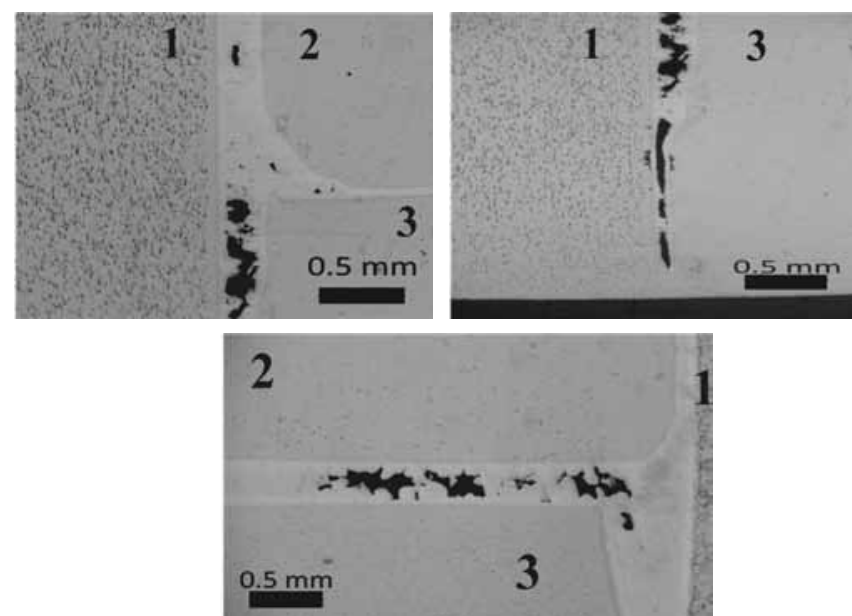

Rys. 17. Połączenie lutowane zespołów filtra olejowego, lut Cu 141: 1 - konektor stalowy, 2 - tuleja dystansowa stalowa, 3 - pokrywka stalowa, w stanie nietrawionym

Fig. 17. Oil filter braze joint: 1 - connector, 2 - spacer, 3 - end cap, non digest

Widoczne pory tworzą miejsca nieszczelności (ujawnione przez badanie penetracyjne). Prawdopodobnym powodem niezgodności są: zbyt mała ilość lutu do wypełnienia istniejącej szczeliny, nierównomierna szczelina, długa droga płynięcia lutu. Sugerowane działania naprawcze to: zwiększenie średnicy drutu pierścionka lutu oraz zmiana konstrukcyjna elementów zespołu w celu zmniejszenia szerokości szczeliny kapilarnej.

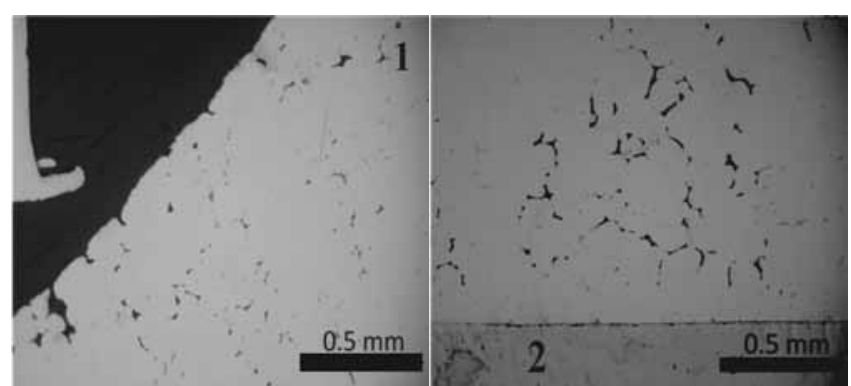

Rys. 18. Wady połączenia lutowanego filtra osuszającego, lut $\mathrm{Cu}$ 922: 1 - konektor miedziany, 2 - pokrywka stalowa, w stanie nietrawionym

Fig. 18. Brazing failures of filter: 1 - copper connector, 2 - end cap, non digest

Na rysunku 18 pokazano połączenie lutowane filtra z niezgodnościami ujawnionymi podczas badań metalograficznych.

Widoczna jest porowatość na całej powierzchni lutowiny. Prawdopodobnym powodem niezgodności są: zbyt wysoka temperatura lutowania, zbyt długi czas lutowania, nieodpowiednio dobrany lut dla połączenia miedź-stal, niewłaściwa atmosfera wodorowa. Sugerowana poprawa jakości połączeń lutowanych: zmiana profilu temperaturowego pieca (obniżenie temperatury lutowania), zmiana lutu na lut Ag54Cu40Zn5Ni1, dobranie odpowiednich parametrów atmosfery redukującej (wymiana filtrów, dodatkowy osuszacz powietrza).

\section{Podsumowanie}

Na podstawie wykonanych badań można sformułować następujące wnioski.

- Proces lutowania twardego w piecach $z$ atmosferą kontrolowaną jest przykładem technologii lutowania o wielu zmiennych parametrach. Każdy parametr ma ogromny wpływ na jakość połączeń lutowanych. Podczas projektowania technologii procesu lutowania należy mieć tego świadomość, inaczej może to prowadzić do błędnych wniosków. Opracowanie technologii dla różnych pod względem konstrukcyjnym elementów wymaga dużej wiedzy teoretycznej oraz wielu prób lutowania.

- Analiza metalograficzna połączeń lutowanych wykazała nieprawidłowości w konstrukcji złącza, których powodem była zbyt szeroka i nierównomierna szczelina lutownicza. Istota projektowania zespołów lutowanych z różnych materiałów (stal, miedź) opiera się na odpowiednim dobraniu szerokości szczeliny lutowniczej, z uwzględnieniem rozszerzalności cieplnej spajanych materiałów.

- Badania metalograficzne stalowych połączeń spawanych, z ujawnionymi pęknięciami, wykazały niekorzystny wpływ nadmiernie rozpłyniętego lutu miedzianego z wykonanego wcześniej, sąsiedniego połączenia lutowanego (lut spływał po pokrywce lub po rysach na szwie rury). Wyniki analizy metalograficznej dają możliwość wprowadzenia zmian procesu technologicznego.

\section{Literatura}

[1] Materiały wewnętrzne firmy.

[2] PN-EN ISO 17672:2010 Lutowanie twarde - spoiwa.

[3] Dokumentacja techniczna pieca BTU.

[4] www.btu.com
[5] Kuta A.: Opracowanie technologii lutowania filtrów osuszających i olejowych w atmosferach kontrolowanych, Praca magisterska wykonana pod kierunkiem prof. Z. Mirskiego, Wydział Mechaniczny Politechniki Wrocławskiej, Wrocław 2013. 